\title{
The Hydrogeological Consequences of the Proposed Extraction of the Deep Groundwater in Jordan
}

\author{
Elias Salameh \\ University of Jordan, Amman, Jordan \\ Email: salameli@ju.edu.jo
}

How to cite this paper: Salameh, E. (2021). The Hydrogeological Consequences of the Proposed Extraction of the Deep Groundwater in Jordan. Journal of Geoscience and Environment Protection, 9, 111-128. https://doi.org/10.4236/gep.2021.98007

Received: July 8, 2021

Accepted: August 13, 2021

Published: August 16, 2021

Copyright $\odot 2021$ by author(s) and Scientific Research Publishing Inc. This work is licensed under the Creative Commons Attribution International License (CC BY 4.0).

http://creativecommons.org/licenses/by/4.0/

\section{(c) (i) Open Access}

\begin{abstract}
Many officials and planners in Jordan have advocated in the last decade extracting the deep brackish, thermal, and salty groundwater resources, desalinate them, and use them for household water supplies. Generally, such groundwater is non-renewable and is found in aquifers underlying fresh renewable groundwater bodies building the base support for them. The deep groundwater feeds the thermal mineralized springs issuing along the eastern escarpment of the Dead Sea-Jordan Rift Valley used for therapeutic purposes. In this article, the geologic set-up of the aquifer series underlying the different parts of the country is outlined to illustrate that all such aquifers extending from ground surface to the impermeable granitic Basement Complex are, in the majority of areas, directly or indirectly interconnected and that extractions from any aquifer, shallow or deep, are effectively taken from the same stock of the groundwater body. Hence, it is concluded that advocating the extraction of the deep salty or brackish groundwater is quasi extracting the same amount of groundwater from the overlying, shallower fresh water aquifers. The deep groundwater issues along the eastern escarpment of the Jordan Rift Valley and is used in household supplies, in irrigation and in spas as curative agent. In addition, the intended use of the deep groundwater to be extracted according to the suggested policy in household supplies requiring desalination, which is a costly unnecessary process accompanied with rigorous environmental ramifications of disposing off the desalination brines.
\end{abstract}

\section{Keywords}

Exploitation Implications, Deep Groundwater, Shallow Groundwater, Interconnectedness, Desalination, Jordan 


\section{Introduction}

Jordan is a country of about $89.000 \mathrm{~km}^{2}$ bordered by Syria in the north, Iraq in the northeast, Saudi Arabia in the East and south and Palestine and Israel in the west (Figure 1). The prevailing climate is semi-arid and precipitation annual rates range from $30 \mathrm{~mm} / \mathrm{yr}$ in the south and south eastern parts of the country to 550 $\mathrm{mm} / \mathrm{yr}$ in the northwestern highlands with potential evaporation rates of 4000 $\mathrm{mm} /$ year and $1600 \mathrm{~mm} /$ year respectively. This results in an average renewable surface and groundwater resources of the country of around $900 \mathrm{MCM} / \mathrm{yr}$ indicating the scarcity of water resources of the country (Salameh et al., 2018; MoWI, 2016; NWMP, 1977).

The Geology of Jordan consists of a granitic basement cropping out in southwest Jordan and dipping towards the north where it becomes gradually covered by clastic rocks of Pre-Cambrian through Lower Cretaceous ages with some missing formations of Devonian, Carboniferous and Lower Permian (Bandel \& Salameh, 2013; Bender, 1975; Burdon, 1959) (Figure 2 and Figure 3). This package of rocks forms one interconnected aquifer having one groundwater table inclined in a northerly direction, with some modifications in the northern parts of the country. The overlying Upper Cretaceous rocks consist of a series of

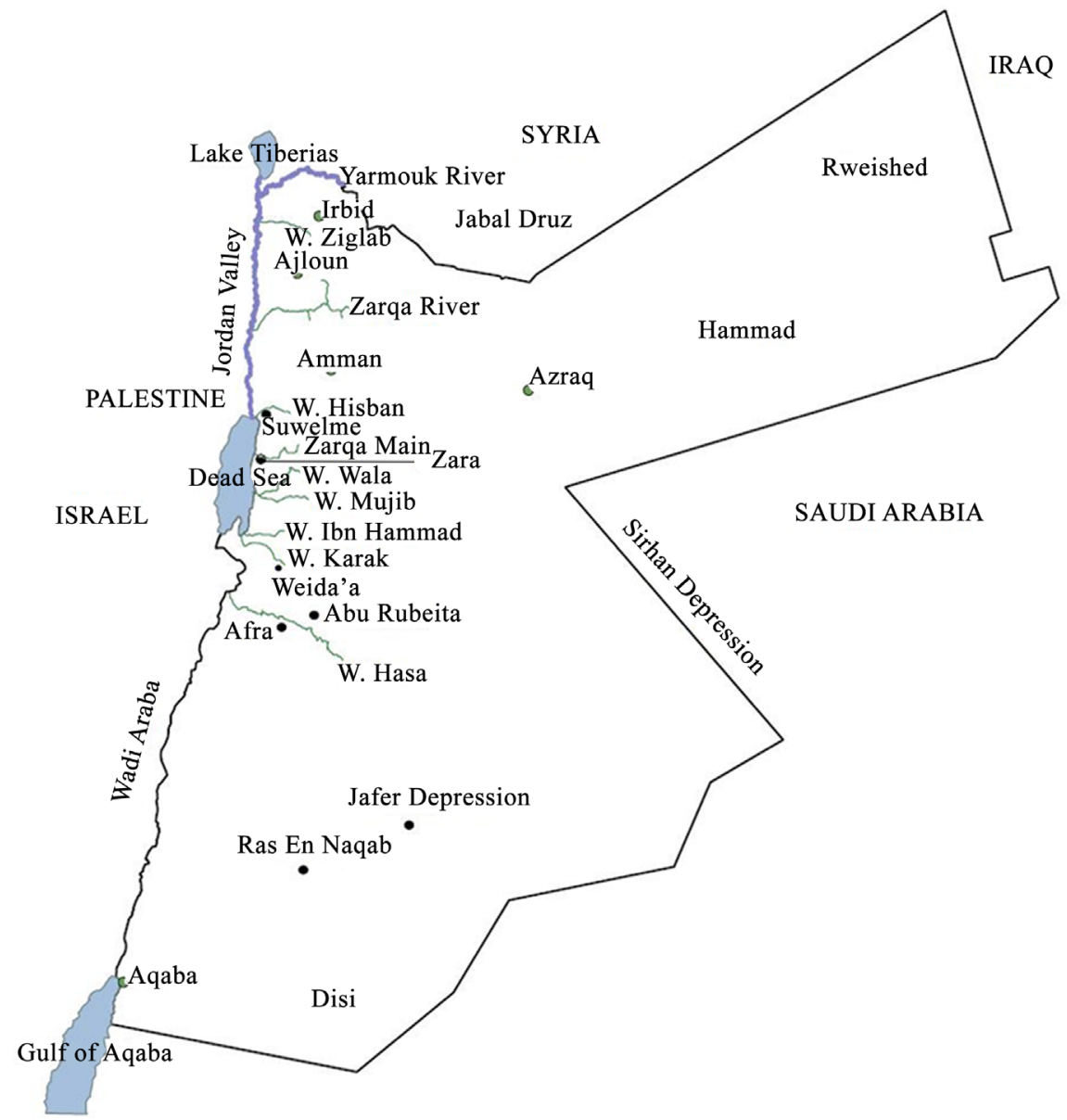

Figure 1. Location map of Jordan and of sites mentioned in the current paper. 


\begin{tabular}{|c|c|c|c|c|c|c|c|c|c|}
\hline ERA & \multicolumn{2}{|c|}{ SYSTEM } & EPOCH & GROUP & FORMATION & SYMBOL & LITHOLOGY & THICKNESS [m] & AQUIFER UNIT \\
\hline \multirow{6}{*}{$\begin{array}{l}0 \\
0 \\
\text { N } \\
0 \\
Z \\
\text { પ્ }\end{array}$} & \multirow{2}{*}{\multicolumn{2}{|c|}{ QUATERNARY }} & Holocene & \multirow{4}{*}{$\begin{array}{l}\text { JORDAN } \\
\text { VALLEY (JV) }\end{array}$} & Alluvium & $\forall \vee>\quad Q a 1$ & Clay, silt, sand, gravel & & \\
\hline & & & Pleistocene & & Lisan & $v \vee>$ JV3 & Marl, clay, evaporates & $>300$ & \\
\hline & \multirow{4}{*}{ 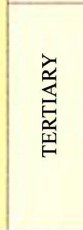 } & \multirow{2}{*}{ 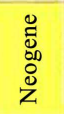 } & Pliocene & & Samra & $\begin{array}{l}1 \\
\text { basalt } \\
\text { basalt }\end{array}$ & Conglomerates & \multirow{2}{*}{$100-350$} & \\
\hline & & & $\begin{array}{l}\text { Miocene } \\
\text { Oligocene }\end{array}$ & & Neogene & vi & Sand, gravel & & \\
\hline & & \multirow{2}{*}{ 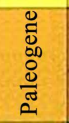 } & Eocene & \multirow{5}{*}{ BALQA (B) } & Wadi Shallala & $1 \mathrm{~B} 5$ & $\begin{array}{l}\text { Chalky and marly } \\
\text { limestone with gloconite }\end{array}$ & $0-550$ & \multirow{2}{*}{ B4/5 (AQUIFER) } \\
\hline & & & Paleocene & & Umm Rijam & B4 & Limestone, chalk, chert & $0-310$ & \\
\hline \multirow{13}{*}{ 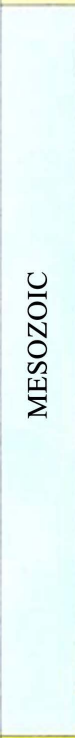 } & \multirow{11}{*}{ 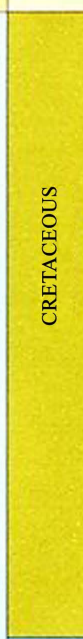 } & \multirow{8}{*}{ ڤัँ } & & & Muwaqqar & B3 & $\begin{array}{l}\text { Chalky marl, marl, } \\
\text { limestone, chert }\end{array}$ & $80-320$ & B3 (AQUITARD) \\
\hline & & & Maastric & & Amman-Al-Hasa & IIB2 & $\begin{array}{l}\text { Limestone, chert, } \\
\text { chalk, phosphorite }\end{array}$ & $20-140$ & \\
\hline & & & Campanian & & W. Umm Ghurdran & पBiा & $\begin{array}{l}\text { Dolomitic marly } \\
\text { limestone, marl, chert, chalk }\end{array}$ & $20-90$ & A7/B2 (AQUIFER) \\
\hline & & & Coniacian & \multirow{5}{*}{ AJLUN (A) } & Wadi as Sir & 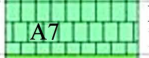 & $\begin{array}{l}\text { Dolomitic limestone, } \\
\text { limestone, chert, marl }\end{array}$ & $60-340$ & \\
\hline & & & Turonian & & Shueib & $\mathrm{A} 5 / 6$ & Marl, limestone & $40-120$ & A5/6 (AQUITARD) \\
\hline & & & \multirow{3}{*}{ Cenomanian } & & Hummar & $\mathrm{A4}$ & Limestone, dolomite & $30-100$ & A4 (AQUIFER) \\
\hline & & & & & Fuheis & $\mathrm{A} 3$ & Marl, limestone & $30-90$ & A3 (AQUITARDS) \\
\hline & & & & & Naur & $\mathrm{A} 1 / 2$ & Limestone, dolomite, marl & $90-220$ & $\mathrm{~A} 1 / 2$ (AQUIFER) \\
\hline & & \multirow{3}{*}{$\begin{array}{l}5 \\
\vdots \\
0 \\
\vdots \\
\vdots\end{array}$} & $\begin{array}{l}\text { Alpian } \\
\text { Aptian } \\
\text { Barremian }\end{array}$ & \multirow{3}{*}{ KURNUB (K) } & \multirow[t]{3}{*}{ Subeihi } & \multirow[t]{3}{*}{$\mathrm{K} 2$} & Sandstone, shale & \multirow{3}{*}{$120-350$} & \multirow{3}{*}{ KURNUB (AQUIFER) } \\
\hline & & & Hauterivian & & & & & & \\
\hline & & & $\frac{\text { Valanginian }}{\text { Berriasian }}$ & & & & Sandstone, shale & & \\
\hline & \multicolumn{2}{|c|}{ JURASSIC } & & \multirow{3}{*}{ ZARQA (Z) } & Azab & E三三三 & $\begin{array}{l}\text { Siltstone, , sandstone, } \\
\text { limestone }\end{array}$ & $0->600$ & \multirow{3}{*}{ ZARQA (AQUIFER) } \\
\hline & \multicolumn{2}{|c|}{ TRIASSIC } & & & Ramtha & $E \equiv \equiv=1$ & $\begin{array}{l}\text { Siltstone, sandstone, shale, } \\
\text { limestone, anhydrite, halite }\end{array}$ & $0->1250$ & \\
\hline \multirow{10}{*}{ 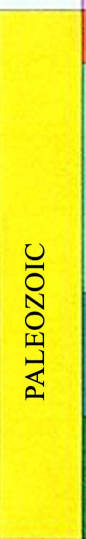 } & PERM & & & & Hudayb & $E \equiv \equiv \exists$ & $\begin{array}{l}\text { Siltstone, sandstone, } \\
\text { limestone }\end{array}$ & $0->300$ & \\
\hline & & & & & Alna & & Siltstone, ,sandstone, shale & $0->1000$ & \\
\hline & & & & & Batra & & Mudstone, siltstone & $0->1600$ & \\
\hline & SILUI & & & KHREIM (KH) & Trebeel & & Sandstone & $0-130$ & KHREIM (AQUIFER) \\
\hline & & & & & Umm Tarifa & & Siltstone, ,Sandstone, shale & $0->1200$ & \\
\hline & & & & & Sahl as Suwwan & & $\begin{array}{l}\text { Mudstone, siltstone } \\
\text { Sandstone }\end{array}$ & $0-200$ & \\
\hline & ORDC & ICIAN & & & Amud & & Sandstone & $0->1500$ & \\
\hline & & & & & Ajram & & Sandstone & 0 - ca 500 & RAM SANDSTONE \\
\hline & CAMI & IAN & & RAM (D) & Burj & & $\begin{array}{l}\text { Siltstone, dolomite, } \\
\text { limestone, sandstone }\end{array}$ & ca 120 & DISI (AQUIFER) \\
\hline & & & & & Salib & & $\begin{array}{l}\text { Arkosic sandstone, } \\
\text { conglomerate }\end{array}$ & $0->750$ & \\
\hline & & & & & $\begin{array}{l}\text { Unaassingned } \\
\text { clastic unit }\end{array}$ & 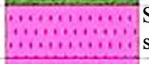 & $\begin{array}{l}\text { Sandstone, argillaceous } \\
\text { siltstone, claystone }\end{array}$ & $0-1000$ & \\
\hline & PREC & MBR & $\mathrm{AN}$ & & Sarmuj & ….................. & Conglomerate sandstone & Up to 420 & BASEMENT \\
\hline & & & & & Aqaba Igneous & : & & & COMPLEX \\
\hline
\end{tabular}

Figure 2. Stratigraphic column of Jordan showing the ages, formations, and types of rocks and their hydraulic classification (Margana et al., 2009).

calcareous rocks forming excellent to poor aquifers and semi aquicludes and cover the area from Ras en Naqab northward into Syria and Iraq. These rocks are topped by Cretaceous Tertiary bituminous marls in Central Jordan extending from Wadi Hasa in the south to Wadi Hisban in the north and from the Dead Sea eastern highlands in the west into Saudi-Arabia in the east. They build 


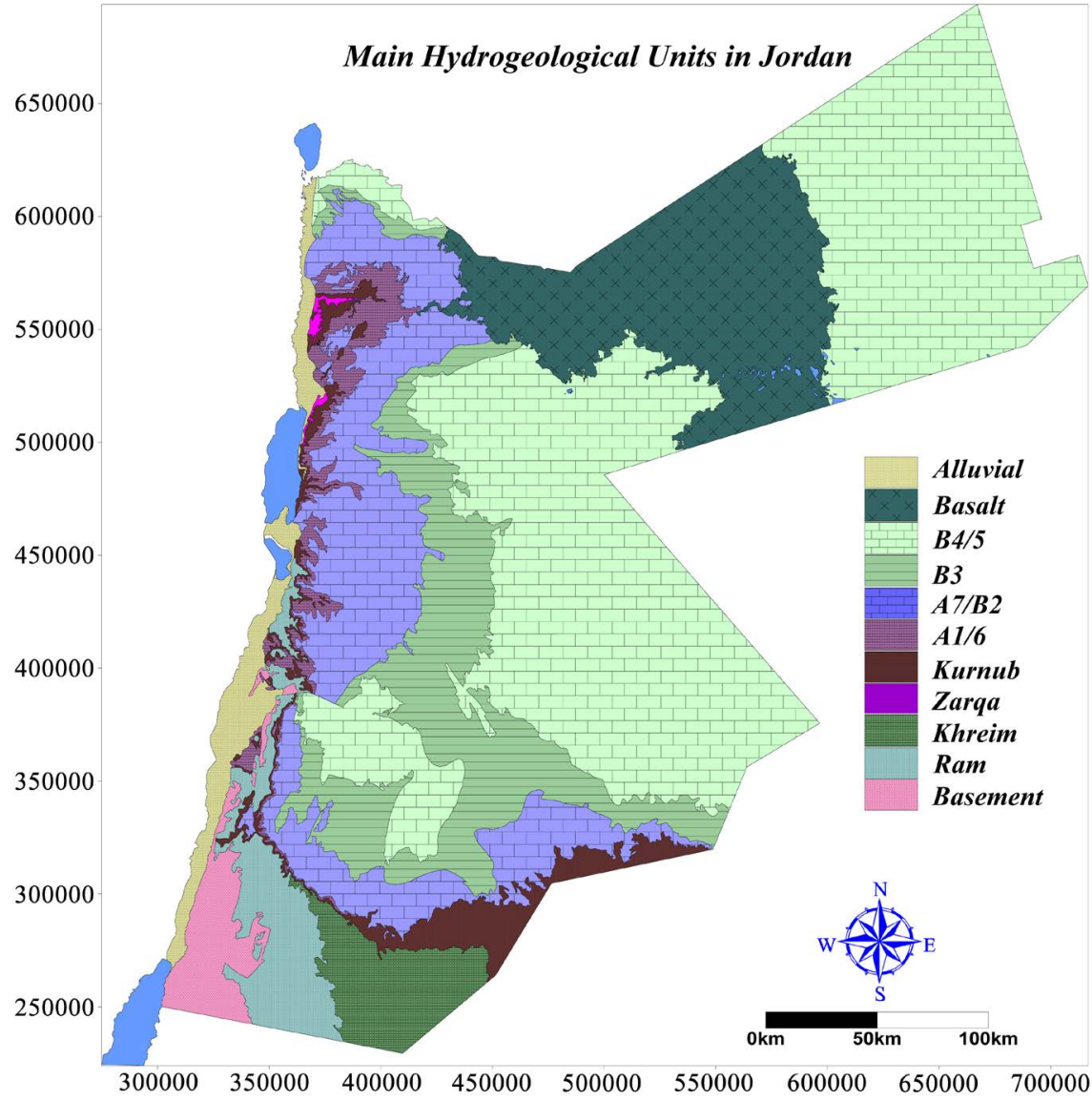

Figure 3. Simplified geological map of Jordan showing the outcrops of the main rock units with the Granitic Basement cropping out in the most southwestern part covered by younger formations in a northeasterly direction (MoWI, 2016).

an aquitard of about 200-300 $\mathrm{m}$ in thickness, confining all older Cretaceous formations (NWMP, 1977; Bender, 1975). Sediments of Eocene and younger Tertiary are only found in Jordan in restricted areas covering depressions such as Azraq and Jafr where they build surficial aquifers having own local groundwater bodies generally separated from older aquifer's groundwater tables.

Jabal Druz basalts cover extended areas in Central North Jordan with a thickness of up to $700 \mathrm{~m}$ in their high mountains part in Jordan thinning out in all directions in a distance of about $50-70 \mathrm{~km}$ (Figure 4). These basalts together with the underlying Tertiary and Upper Cretaceous rock units form a composite aquifer that leaks down groundwater into the deep sandstone aquifer system and recharge it (BGR, 1997; Ibrahim, 1993; Van der Boom \& Suwwan, 1966).

The existing knowledge about the geology and hydrogeology of Jordan is documented in some books and the information used in this article is based on these publications (NWMP, 1977; Bandel \& Salameh, 2013; Burdon, 1959; Ibrahim, 1993; Bender, 1975), in a number of reports (MOWI, 2016; NRA, 2008; Exact, 1998; JICA, 1996; GITEC et al., 1995) and in many scientific articles (Salameh et al., 2018; BGR \& WAJ, 1996; Parker, 1970) and many others. 


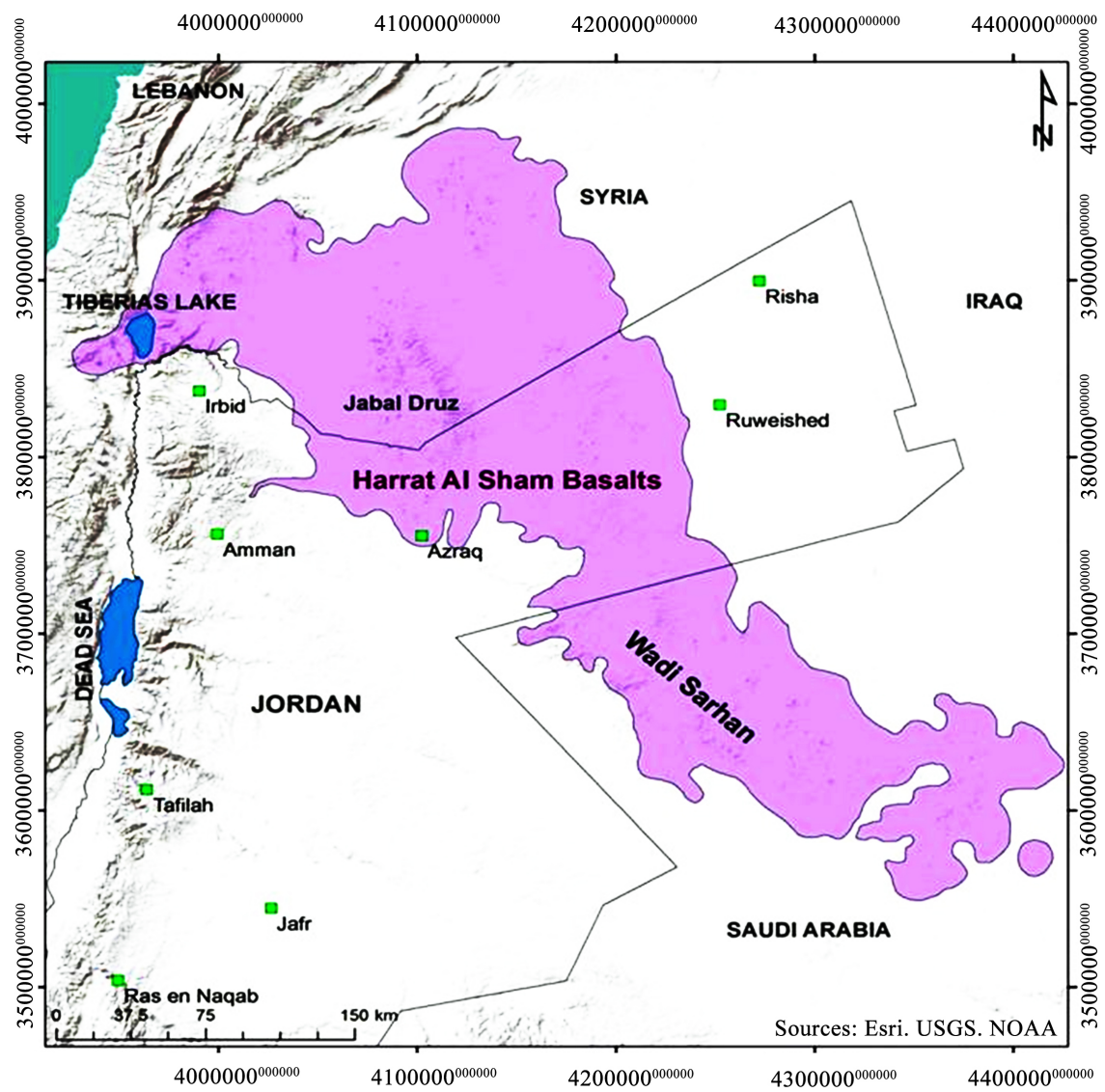

Figure 4. Jabal Druz (Harrat esh Sham) Basalts extending from southwest Syria, through central north Jordan into Saudi-Arabia based on (BGR \& WAJ, 1996). The main recharge takes place in the rain-rich northwestern parts of Jordan and Syria.

In this article the interconnectedness of the different groundwater bodies in Jordan is discussed in order to clarify the impacts of the suggested extraction of the deep brackish and salty groundwater e.g., (Subah, 2019; Gnaneswar, 2018), on the shallow freshwater bodies, and on the deep aquifer's spring discharges which are in use for drinking, industry, irrigation and therapeutic purposes. This is in so far of utmost importance because the shallow aquifers' fresh groundwater is under severe over-exploitation and its water quality is deteriorating with time (Salameh \& Shteiwi, 2019; Salameh, 2008, 1996).

\section{Geologic Set-Up Relevant to Hydraulic Aquifers' Interconnectedness}

The geology of Jordan consists, in general, of a granitic Basement Complex as a part of the Arabian Shield cropping out in the most southwestern part of the country inclined in a northeastern direction where it becomes gradually covered by a series of sedimentary rocks of Precambrian to recent ages (Figures 2-4). Directly overlying that Basement Complex a series of conglomerates, greywacke and clay schist of Precambrian age is found overlain by thick clastic sediments with thin horizons of dolomite and limestone. This rock series forms, even on a 
local scale, one very thick and interconnected aquifer of more than $1200 \mathrm{~m}$ in thickness in southern Jordan increasing to a few thousand meters in the northeast.

No rocks of Devonian and Carboniferous ages were found outcropping or in boreholes in Jordan (Bandel \& Salameh, 2013; Bender, 1975; NRA, 2016).

Upper Permian sandstone, conglomerate and a few layers of limestone rocks start to appear east of the middle part of the Dead Sea, Wadi Wala, and extend northward, where they become covered by Triassic sand, siltstone, calcareous sand and thin layers of conglomerates and claystone. Further north, in the area just north of the Dead Sea northeastern shore Jurassic siltstones, evaporates and sandy limestone crop out and increase in thickness in a northerly direction. In general, Permian, Triassic and Jurassic rocks are considered good to medium aquifers with some aquicludes which are very limited in their horizontal extensions. Therefore, the whole series; Permian to Jurassic forms one interconnected aquifer.

Lower Cretaceous sandstones underlie almost all parts Jordan. They cover parts of the outcropping granitic Basement Complex and older Paleozoic rocks in the southwestern part of the country and extend in a north eastern direction to be encountered outcropping or in boreholes in all parts of the country. This sandstone package builds a very good aquifer in Jordan (Figure 3 and Figure 5).

Directly overlying the Lower Cretaceous sandstone, a series of calcareous rocks follows. It consists of limestone, dolomite, marlstone, and chert rocks of more than $600 \mathrm{~m}$ in thickness in the northern part of the country. This calcareous rock series is of Upper Cretaceous age and contains thick aquifers but with some aquicludes.

The top formation of the Upper Cretaceous rock series, which continues into the Tertiary, is built of the so called Muwaqqar Formation, which consists of marlstone bearing in most parts of its extensions bitumen and has a thickness of 200 - 300 m. This Marl Formation is the major aquiclude in Jordan and is found

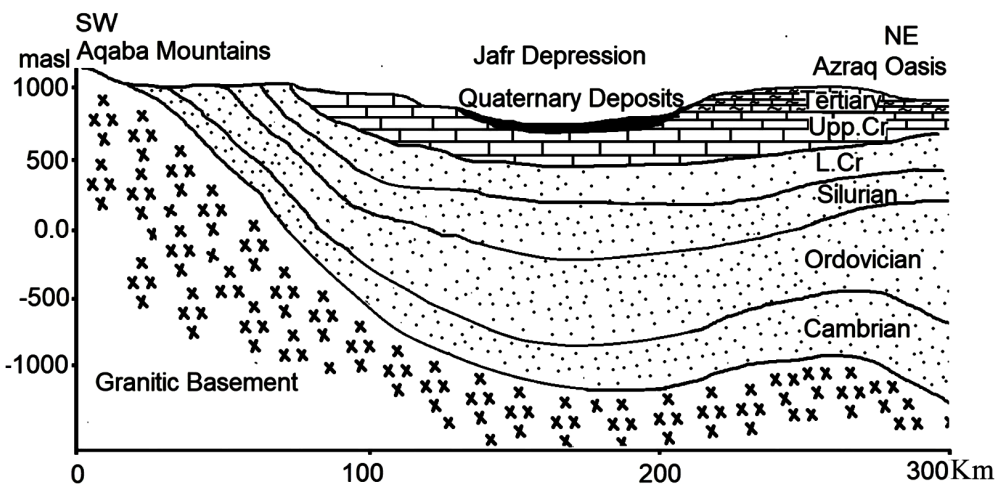

Figure 5. Simplified geological cross section from Aqaba in the southwest to Azraq in the north east. It shows the granitic Basement overlain by a thick series of clastic rocks of Cambrian, Ordovician Silurian and Lower Cretateous ages overlain by a calcareous series of Upper Cretaceous rocks and in Azraq area the letter is overlain by chalkylimestone of Tertiary age. 
to cover areas lying to the east of the high mountains east of the Dead Sea towards the Saudi Arabia borders and also at the southern flank of the Yarmouk River confining the underlying aquifers.

Overlying the Muwaqqar Bituminous Marl Formation a Tertiary chalk marl aquifer covers the most northwestern area of Jordan and Azraq and Jafr depression. It is called the Chalk Marl Unit.

Basalts cover in Central North Jordan extended areas, of about $11 \%$ of the country's total area, with a thickness reaching around $700 \mathrm{~m}$ in Jordan. They build a major aquifer in southern Syria and central north Jordan (Figure 4). The surficial aquifers form different groundwater basins (Figure 6).

\section{Geologic Profiles}

From the above short lithostratigraphic description of the geologic column in relation to aquifer characteristics, it can be stated that only a few aquifer-aquiclude profile constellations can be recognized in the country. These are summarized in the following:

1) In southern Jordan; Disi to Hasa River area (East of the southern shore of the Dead Sea) the rock column is built of Cambrian, Ordovician, Silurian and lower Cretaceous sandstones and to the north of Ras en Naqab Escarpment they are covered by Upper Cretaceous calcareous sandy aquifers (Table 1 and Table 2). The rock columns there from Pre-Cambrian to the bottom of the calcareous

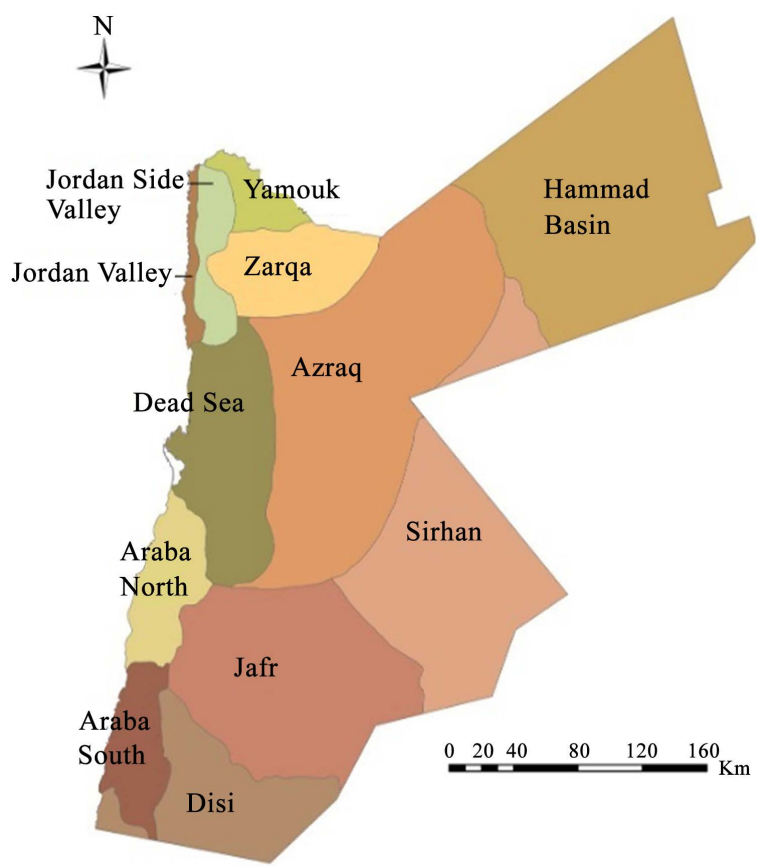

Figure 6. Approximate boundaries of surficial groundwater basins in Jordan. The deep groundwater body in the clastic Pre-Cambrian through Lower Cretaceous formations build one horizontally and vertically interconnected aquifer with direct recharge mouths in Disi, Baqa'a, Mahis and Zarqa River down-stream area, and along the eastern escarpment of the Dead Sea and indirect recharge all over the country, where these formations are overlain by Cretaceous, Tertiary, basaltic and recent rocks. 
Table 1. Geologic column in Disi Mudawwara area.

\begin{tabular}{ccccc}
\hline Formation age & Thickness $(\mathrm{m})$ & Type of rocks & $\begin{array}{c}\text { Main hydraulic } \\
\text { characteristics }\end{array}$ & General consideration \\
\hline Lower Cretaceous & $70-150$ & $\begin{array}{c}\text { Mainly } \\
\text { coarse-grained } \\
\text { sandstone with } \\
\text { some clay lenses }\end{array}$ & One aquifer & $\begin{array}{c}\text { One major } \\
\text { interconnected } \\
\text { sandstone and siltstone } \\
\text { aquifer containing } \\
\text { fresh water }\end{array}$ \\
Ordovician & $820-970$ & $\begin{array}{c}\text { Coarse, medium and fine-grained sandstone } \\
\text { with some silt and conglomerate }\end{array}$ & $\begin{array}{c}\text { One inter-connected } \\
\text { aquifer }\end{array}$ & Aquifuge \\
Granitic basement & $380-400$ & Mainly granite & & \\
\hline
\end{tabular}

Table 2. Geologic column in the area North of Ras en Naqab to Wadi Hasa.

\begin{tabular}{|c|c|c|c|c|}
\hline Formation age & Type of rocks & Thickness (m) & $\begin{array}{l}\text { Main hydraulic } \\
\text { characteristics }\end{array}$ & General consideration \\
\hline Surficial recent deposits & $\begin{array}{l}\text { Recent gravels, } \\
\text { sand and silt }\end{array}$ & Up to $30 \mathrm{~m}$ & $\begin{array}{c}\text { Local aquifer } \\
\text { when conditions allow }\end{array}$ & $\begin{array}{l}\text { Irrelevant as a } \\
\text { source of water }\end{array}$ \\
\hline $\begin{array}{c}\text { Upper } \\
\text { Cretaceous-Tertiary }\end{array}$ & Bituminous Marl & $\begin{array}{c}\text { Only in } \\
\text { small outcrops }\end{array}$ & Aquiclude & Aquiclude \\
\hline $\begin{array}{c}\text { Campanian } \\
\text { Maastrichtian }\end{array}$ & $\begin{array}{l}\text { Silicified limestone overlain } \\
\text { by beds of phosphatic chert }\end{array}$ & Around $70 \mathrm{~m}$ & Excellent aquifer & Good to excellent Aquifer \\
\hline Turonian-Santonian & Massive sandy limestone & $55 \mathrm{~m}$ & Good aquifer & \\
\hline Cenomanian & $\begin{array}{l}\text { Alternating beds of limestone, } \\
\text { dolomite, marly limestone, } \\
\text { dolomitic limestone, sandstone, } \\
\text { marl and some gypsum layers }\end{array}$ & Around $300 \mathrm{~m}$ & $\begin{array}{l}\text { Poorly developed aquifer. } \\
\text { In many areas springs issue } \\
\text { from the limestone } \\
\text { and dolomite beds }\end{array}$ & $\begin{array}{l}\text { In general, poorly developed } \\
\text { aquifer with some good yield } \\
\text { aquifer layers. On a regional } \\
\text { scale it leaks water down } \\
\text { into the older aquifers }\end{array}$ \\
\hline Lower Cretaceous & $\begin{array}{l}\text { Coarse, medium and } \\
\text { fine-grained sandstone }\end{array}$ & $150 \mathrm{~m}$ & Good aquifer & $\begin{array}{l}\text { Good to excellent aquifer } \\
\text { directly overlying } \\
\text { Silurian sandstones }\end{array}$ \\
\hline $\begin{array}{l}\text { Silurian-Cambrian } \\
\text { sandstone series }\end{array}$ & $\begin{array}{l}\text { Mainly coarse, medium and } \\
\text { coarse-grained sandstone }\end{array}$ & $1300-1400 \mathrm{~m}$ & Excellent aquifer & Excellent aquifer \\
\hline
\end{tabular}

Upper Cretaceous rocks contain no aquicludes. The Upper Cretaceous calcareous rock series contains thick beds of marl, clay and mud which can be considered as aquitards on a regional scale, but the thick beds of limestone and dolomite form good aquifers. In addition, in the Jafr depression a thick lens of bituminous marl is found underlying the central part of the Depression that thins out in all directions. Recharge takes place mainly in the highlands east of Wadi Araba and the recharged water into the Upper Cretaceous rocks flows in an easterly direction towards the eastern Plateau of the country. During that, parts of the recharge water percolate down and reach the underlying sandstone aquifers carrying with it some salts dissolved from the evaporate residues deposited with the Upper Cretaceous rocks. In a northeasterly direction, from Ras en Naqab Escarpment onward two groundwater tables start to establish themselves; the deeper groundwater table of the sandstone aquifers and the shallower ground- 
water table of the Upper Cretaceous aquifers. Nonetheless, leakages from the Upper Cretaceous aquifers continue along faults, fractures and weakness zones.

Therefore, in this area, the rock column overlying the granitic basement through the Upper Cretaceous forms one regional aquifer.

2) The area extending from Hasa River area to Wadi Hisban area at the NE edge of the Dead Sea (It is the area east of the Dead Sea) to Wadi Sirhan Depression at the borders to Saudi Arabia is underlain by interconnected aquifers from the Pre-Cambrian rocks to Lower Cretaceous (Table 3). They are overlain by alternating Upper Cretaceous aquifers and semi-aquifers topped by $200-300 \mathrm{~m}$ of a bituminous marl aquiclude, confining all older, horizontally and vertically interconnected, aquifers. Here it is found that all underlying geologic formations of the surficial bituminous marl aquiclude build two groundwater bodies; the deep sandstone water body having its groundwater table deeper than the shallow Upper Cretaceous aquifer body (Figure 7). Leakages from the shallow groundwater body into the deep groundwater take place along fractures, joints and faults carrying with them dissolved residual evaporate salts.

In this area, to the north of wadi Mujib Latitude, intercalations of Upper Permian and Triassic siltstone, sandstone calcareous sandstone, and some claystone start to appear and to increase in thickness in a northerly direction, from about 160 to some $400 \mathrm{~m}$ at the northeastern edge of the Dead Sea and to $660 \mathrm{~m}$ in

Table 3. Geologic column in plateau area east of the dead sea.

\begin{tabular}{|c|c|c|c|c|}
\hline Formation age & Type of rocks & Thickness (m) & $\begin{array}{l}\text { Main hydraulic } \\
\text { characteristics }\end{array}$ & General consideration \\
\hline Surficial recent deposits & $\begin{array}{l}\text { Recent gravels, } \\
\text { sand and silt }\end{array}$ & $\mathrm{Up}$ to $30 \mathrm{~m}$ & $\begin{array}{l}\text { Local aquifer when } \\
\text { conditions allow }\end{array}$ & $\begin{array}{l}\text { Irrelevant as a } \\
\text { source of water }\end{array}$ \\
\hline Upper Cretaceous-Tertiary & Bituminous Marl & $200-300 \mathrm{~m}$ & Aquitard & Aquitards, confining layer \\
\hline Campanian Maastrichtian & $\begin{array}{l}\text { Silicified limestone overlain } \\
\text { by beds of phosphatic chert }\end{array}$ & Around $70 \mathrm{~m}$ & Excellent aquifer & Good to excellent Aquifer \\
\hline Turonian-Santonian & Massive sandy limestone & $55 \mathrm{~m}$ & Good aquifer & \\
\hline Cenomanian & $\begin{array}{l}\text { Alternating beds of limestone, } \\
\text { dolomite, marly limestone, } \\
\text { dolomitic limestone, sandstone, } \\
\text { marl and some gypsum layers }\end{array}$ & Around $300 \mathrm{~m}$ & $\begin{array}{l}\text { Poorly developed } \\
\text { aquifer. In many } \\
\text { areas springs issue } \\
\text { from the limestone } \\
\text { and dolomite beds }\end{array}$ & $\begin{array}{c}\text { In general, poorly } \\
\text { developed aquifer with } \\
\text { some good yields aquifer } \\
\text { layers. On a regional scale it } \\
\text { doesn't form an aquiclude }\end{array}$ \\
\hline Lower Cretaceous & $\begin{array}{l}\text { Coarse, medium and fine-grained } \\
\text { sandstone }\end{array}$ & $160-200 \mathrm{~m}$ & Good aquifer & $\begin{array}{l}\text { Good to excellent aquifer, } \\
\text { S of Mujib directly overlie } \\
\text { Silurian deposits }\end{array}$ \\
\hline Triassic & $\begin{array}{l}\text { Siltstone, sandstone } \\
\text { calcareous sandstone }\end{array}$ & $\begin{array}{l}0 \mathrm{~m} \text { Just } \mathrm{N} \text { of Mujib, } \\
>400 \mathrm{~m} \text { at the NE } \\
\text { edge of the Dead Sea }\end{array}$ & Poor to good & $\begin{array}{l}\text { Gradually, in a } \mathrm{N} \text { direction } \\
\text { containing brackish water }\end{array}$ \\
\hline Permian & $\begin{array}{l}\text { Sandstone, siltstone, } \\
\text { conglomerate }\end{array}$ & $\begin{array}{l}0 \mathrm{~m} \mathrm{~N} \text { of Mujib-300 m } \\
\text { in the NE }\end{array}$ & Good aquifer & $\begin{array}{l}\text { Good aquifer containing } \\
\text { fresh to brackish water }\end{array}$ \\
\hline $\begin{array}{l}\text { Silurian-Cambrian } \\
\text { sandstone series }\end{array}$ & $\begin{array}{l}\text { Mainly coarse, medium and } \\
\text { coarse-grained sandstone }\end{array}$ & $1300-1400 \mathrm{~m}$ & Excellent aquifer & Excellent aquifer \\
\hline
\end{tabular}




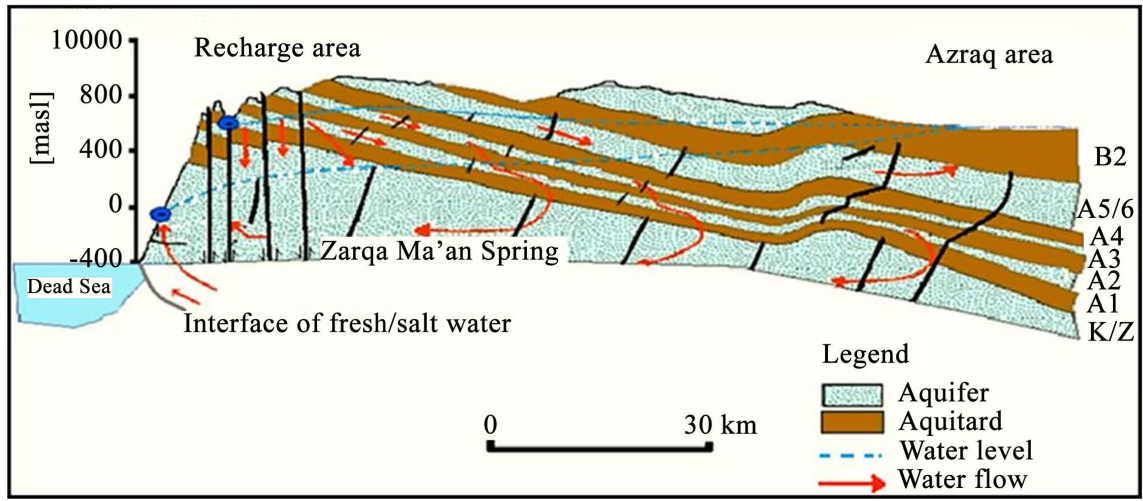

Figure 7. Schematic hydrogeological cross section from the Dead Sea in the west to Azraq area in the east showing the groundwater flows in the Upper Cretaceous calcareous rocks and in the underlying sandstone aquifer series of Lower Cretaceous to Cambrian ages (Salameh \& Udluft, 1985) modified in (Salameh et al., 2018).

Wadi Zarqa area. The Upper Permian/Triassic rocks in this area form a good aquifer connecting the underlying Silurian sandstone with the overlying Lower Cretaceous sandstones forming one interconnected aquifer from Pre-Cambrian to the top of the Lower Cretaceous sandstone which in turn is hydraulically connected with the Upper Cretaceous rock series of excellent to poor aquifers.

Triassic rocks may contain some evaporate residues and their groundwater becomes brackish in a northerly direction, especially when considering the down percolation of the groundwater from the lower Upper Cretaceous rocks, containing evaporate residues, through the Lower Cretaceous sandstones into Permo-Triassic rocks.

The calcareous Upper Cretaceous rocks are covered by the thick surficial Bituminous Marl aquiclude confining all older rock series which form one horizontally and vertically interconnected aquifer. Therefore, groundwater extraction from any part within that aquifer series can be considered as extraction from the same groundwater body. And in this area,, east of the Dead Sea extractions through wells will negatively affect the discharge of the thermal mineralized springs presently used for curative purposes in Afra, Wadi Ibn Hammad, Zarqa Ma'in, Zara and Suweima.

3) In the area east of the Jordan Valley, from Wadi Hisban in the south to Wadi Ziglab in the north and to the east of the eastern highlands of the Jordan Valley a series of very good to poor aquifers build the rock column from the Triassic and underlying rocks to the ground surface (Table 4). This rock column is hydraulically interconnected, but there are some rock formations with poor aquifer characteristics but on a regional scale they function as vertical and horizontal water conduits allowing the groundwater in the Upper Cretaceous aquifers to infiltrate down and recharge the older sandstone aquifer series (Salameh \& Tarawneh, 2017; Tarawneh, 2015). Here also, water extractions from any part of the groundwater body will be on the account of the stored fresh groundwater resources. 
Table 4. Geologic column in the area east of the Jordan Valley eastern highlands.

\begin{tabular}{|c|c|c|c|c|}
\hline Formation age & Type of rocks & Thickness (m) & Main hydraulic characteristics & General consideration \\
\hline Paleocene Eocene & Chalk marls & $0-60 \mathrm{~m}$ & Medium aquifer & \\
\hline $\begin{array}{c}\text { Maastrichtian } \\
\text { Paleocene }\end{array}$ & Bituminous marl & $200-300 \mathrm{~m}$ & Aquitard, confining layers & Only to the NW of Irbed City \\
\hline $\begin{array}{c}\text { Campanian } \\
\text { Maastrichtian }\end{array}$ & $\begin{array}{l}\text { Silicified limestone overlain } \\
\text { by beds of phosphatic chert }\end{array}$ & Around $70 \mathrm{~m}$ & Excellent aquifer & Main water aquifer \\
\hline Turonian & Marl lenses & $0-20 \mathrm{~m}$ & Lenses of an aquiclude & $\begin{array}{l}\text { On very small scale } \\
\text { of } 100 \mathrm{~m} \text { aquiclude }\end{array}$ \\
\hline Turonian Santonian & Massive sandy limestone & $60 \mathrm{~m}$ & Excellent aquifer & Excellent karst aquifer \\
\hline Cenomanian & $\begin{array}{l}\text { Alternating beds of limestone, } \\
\text { dolomite, marly limestone, } \\
\text { sandstone, marl and } \\
\text { some gypsum layers }\end{array}$ & Around $300 \mathrm{~m}$ & $\begin{array}{l}\text { Poorly developed aquifer. } \\
\text { In many areas springs issue } \\
\text { from the limestone } \\
\text { and dolomite beds }\end{array}$ & $\begin{array}{c}\text { In general, poorly } \\
\text { developed aquifer with some } \\
\text { good yields aquifer layers }\end{array}$ \\
\hline Lower Cretaceous & $\begin{array}{l}\text { Coarse, medium and } \\
\text { coarse-grained sandstone }\end{array}$ & $200 \mathrm{~m}$ & Good aquifer & Good to excellent \\
\hline Jurassic & $\begin{array}{l}\text { Sandstone, limestone, } \\
\text { dolomite, evaporates }\end{array}$ & $440 \mathrm{~m}$ & Medium to poor aquifer & Containing brackish water \\
\hline Triassic & $\begin{array}{l}\text { Siltstone, sandstone } \\
\text { calcareous sandstone }\end{array}$ & $660 \mathrm{~m}$ & Medium aquifer & Containing brackish water \\
\hline
\end{tabular}

In the area northwest of Irbed City extending from Wadi Ziglab to the Yarmouk River, east of the Jordan Valley the Bituminous Marl Unit build an aquiclude that separates all underlying, horizontally and vertically interconnected series of good and poorly developed aquifers from the overlying surficial chalk marl aquifer (ElNasser, 1991; Bajjali et al., 1997). The hydrogeological situation here resembles that of the area east of the high mountains overlooking the Dead Sea (Area 2 above).

4) The basalt area of Jabal Druz (Figure 4) which occupies around $11 \%$ of Jordan's territory is covered by a series of generally very good basaltic aquifers of up to $700 \mathrm{~m}$ in thickness in Jordan, but in a depth of a few hundred meters some poorly developed aquifers are found. In general, the geologic column from a depth of more $1000 \mathrm{~m}$ to ground surface is built by a thick combination of basalts, limestone, dolomite, phosphate, chalk marls and chert, which form one hydraulically interconnected aquifer containing fresh water (Table 5).

5) The area of the Pan-Handle is covered by limestone, chert, silicified limestone, sandy limestone, phosphates and basalts all forming one aquifer of about $800 \mathrm{~m}$ in thickness underlain by the Maastrichtian-Paleocene marl aquiclude of about $700 \mathrm{~m}$ in thickness (Table 6). The surficial aquifer contains brackish, (1200 $2500 \mu \mathrm{S} / \mathrm{cm}$ ) none-renewable groundwater which is poorly recharged by occasional floods along wadis or by infiltration of floodwater that collects in desert playas. The salinity of the groundwater in the Upper Cretaceous formations increases to around $5000 \mu \mathrm{S} / \mathrm{cm}$.

\section{Results and Discussion}

The above summarization of the aquifer/aquiclude characteristics of the rock columns in Jordan lead to the following statements. 
Table 5. Geologic column in Jabal Druz basalt area.

\begin{tabular}{|c|c|c|c|c|}
\hline Formation age & Type of rocks & Thickness (m) & Main hydraulic characteristics & General consideration \\
\hline Basalts & Basalts, scoria, tuff & Up to $700 \mathrm{~m}$ & Excellent aquifer & $\begin{array}{l}\text { Shallow aquifer connected } \\
\text { with all underlying aquifers }\end{array}$ \\
\hline Paleocene Eocene & Chalk marls & $0-40 m$ & Medium aquifer & $\begin{array}{l}\text { Only encountered } \\
\text { in some places }\end{array}$ \\
\hline Campanian Maastrichtian & Silicified limestone & Around $70 \mathrm{~m}$ & Excellent aquifer & Main water aquifer \\
\hline Turonian & Marl lenses & $0-20 \mathrm{~m}$ & Lenses of an aquiclude & $\begin{array}{l}\text { On very small scale } \\
\text { of } 100 \mathrm{~m} \text { aquiclude }\end{array}$ \\
\hline Turonian Santonian & Massive sandy limestone & $60 \mathrm{~m}$ & Excellent aquifer & Excellent karst aquifer \\
\hline Cenomanian & $\begin{array}{c}\text { Alternating beds of } \\
\text { limestone, dolomite, } \\
\text { marly limestone, sandstone, } \\
\text { marl and some gypsum layers }\end{array}$ & Around $300 \mathrm{~m}$ & Poorly developed aquifer. & $\begin{array}{c}\text { In general, poorly } \\
\text { developed aquifer with } \\
\text { some good yields layers }\end{array}$ \\
\hline Lower Cretaceous & $\begin{array}{c}\text { Coarse, medium and } \\
\text { coarse-grained sandstone }\end{array}$ & $210 \mathrm{~m}$ & Good aquifer & Good to excellent \\
\hline
\end{tabular}

Table 6. Geologic column in the pan handle area: Wadi Rajil Well No.1 (GITEC et al., 1995).

\begin{tabular}{ccccc}
\hline Formation age & Type of rocks & Thickness $(\mathrm{m})$ & $\begin{array}{c}\text { Main hydraulic } \\
\text { characteristics }\end{array}$ & General consideration \\
\hline Miocene & $\begin{array}{c}\text { Sandstone, chalky } \\
\text { limestone, chert nodules }\end{array}$ & $\begin{array}{c}40 \mathrm{~m}, \\
\text { elsewhere up to } 100 \mathrm{~m}\end{array}$ & Intermediate aquifer & Aquifer, with some aquiclude \\
Paleocene Eocene & Chalk marls & $660 \mathrm{~m}$ & Medium aquifer \\
Maastrichtian Paleocene & Marl & $695 \mathrm{~m}$ & Aquiclude, confining layers & Aquiclude \\
Maastrichtian-Cenomanian & $\begin{array}{c}\text { Silicified limestone, } \\
\text { phosphatic chert } \\
\text { Marl, dolomite } \\
\text { marly limestone }\end{array}$ & Around $220 \mathrm{~m}$ & Excellent to poor aquifer & $\begin{array}{c}\text { In general, poorly developed } \\
\text { aquifer with some good } \\
\text { yields aquifer layers }\end{array}$ \\
Lower Cretaceous & $\begin{array}{c}\text { Coarse, medium and } \\
\text { coarse-grained sandstone }\end{array}$ & $150 \mathrm{~m}$ & Good aquifer & Good to excellent aquifer
\end{tabular}

1) In the area extending from Aqaba to Ras En Naqab Escarpment in the west towards the border with Saudi-Arabia in the east all the rock units from the granitic Basement Complex to ground surface are composed of different vertically and horizontally interconnected sandstone and carbonate aquifers (Bender, 1975), which contain fresh $(350-850 \mu \mathrm{S} / \mathrm{cm}$ ) but fossil groundwater (Figure 5). In this area groundwater extractions from the deep, intermediate or shallow groundwater are taken from the same groundwater body and that drilling of deep wells to extract the deep groundwater is a misleading concept.

The conclusion is that all extractions wherever and from which depth the groundwater is taken from the same groundwater stock.

To the north of Ras en Naqab Escarpment to Wadi Hasa area, Cambrian, Ordovician, Silurian and Lower Cretaceous sandstones are covered by Upper Cretaceous calcareous sandy rocks (Bandel \& Salameh, 2013; Bender, 1975). The rock columns there from Pre-Cambrian to the bottom of the calcareous Upper 
Cretaceous rocks contain no aquicludes. The Upper Cretaceous calcareous rock series contains some thick beds of marl, clay and mud which can be considered as aquicludes on a local scale. In addition, in the Jafr depression a thick lens of bituminous marl is found underlying the central part of the Depression that thins out in all directions. In a northeasterly direction from Ras en Naqab Escarpment two groundwater tables start to establish themselves; the deeper groundwater table of the sandstone aquifers and the shallower groundwater table of the Upper Cretaceous aquifers. Nonetheless, the two groundwater bodies remain hydraulically interconnected and interflows between the two groundwater bodies exist by groundwater percolating down from the Upper Cretaceous groundwater body into the deep sandstone groundwater body. Here all groundwater extractions from any area or aquifer are to be considered extractions from the same groundwater body. Where the two groundwater bodies become semi separated, near Hasa, the deep sandstone groundwater becomes thermal, containing iron, radon and other curative agents and discharges along Wadi Hasa and its tributary wadis to be used in curative purposes (Afra, Burbeita and other thermal springs) (Salameh \& Rimawi, 1997). Therefore, any extractions of the deep sandstone groundwater in the up- or down-gradient areas of these thermal springs will have its rigorous implications to these curative springs' productivity, their uses and the investments in spa projects depending on their water.

2) Along the highlands east of the Dead Sea, the outcropping aquifers, mainly composed of Upper Cretaceous limestone, dolomite, chert, and phosphate rocks in addition to Lower Cretaceous sandstones are recharged by precipitation. The built-up groundwater flows either eastward and discharge along westerly draining wadis or it continues in an easterly direction towards the Sirhan Depression in Saudi Arabia. The area to the east of the highlands, the plateau area, is covered by a surficial aquiclude, namely the bituminous marls of $200-300 \mathrm{~m}$ in thickness, confining all underlying aquifers. The deep sandstone aquifer complex (Pre-Cambrian to Lower Cretaceous) builds a single groundwater body flowing towards the Dead Sea (Salameh \& Udluft, 1985) (Figure 7). The overlying Upper Cretaceous formations contain thick alternating beds of aquifers and aquicludes which locally have their own water bodies but are interconnected within the whole Upper Cretaceous rock series overlain on the Plateau by the confining Bituminous Marl aquiclude. The groundwater in the Upper Cretaceous aquifers is recharged in the highlands area and the groundwater flows east, where it becomes confined by the overlying bituminous marls. Along its easterly flow direction, the groundwater leaks into the deep sandstone aquifer and contributes to its salinity (Salameh \& Udluft, 1985).

In the southern part of the area, south of Wadi Wala the groundwater body in the sandstone aquifer is fresh of up to $1100 \mu \mathrm{S} / \mathrm{cm}$ electric conductivity.

In the area north of Wadi Wala course intercalations of Permian and Triassic sandstone, siltstone and marls containing some evaporate residues start gradually to separate the deep Paleozoic sandstone series from the Lower Cretaceous sandstones (Bender, 1975). And further north at the north eastern edge of the 
Dead Sea Jurassic sandstone and carbonate rocks start to appear, also these contain thick beds of evaporates (up to $40 \mathrm{~m}$ in thickness). The groundwater passing through the Permian, Triassic and Jurassic rocks attains higher salinities reaching $3000 \mu \mathrm{S} / \mathrm{cm}$ in Zarqa Ma'in and around $7000 \mu \mathrm{S} / \mathrm{cm}$ in Suweima area at the northeastern edge of the Dead Sea. The discharged water in these areas is thermal and mineralized and is used for therapeutic purposes.

Here also it can be concluded that the whole rock units underlying the surficial Bituminous Marl aquiclude down to the deep Paleozoic sandstone aquifer form one groundwater body and groundwater extractions, from any depth or area, are to be considered extractions from the same groundwater stock. In this area, any groundwater extractions from the deep sandstone aquifer will be on the account of the utilized thermal mineralized curative waters of Weda'a, Wadi Ibn Hammad, Zarqa Ma'in, Zara, and Hisban springs which issue from this sandstone aquifer series.

3) The high mountains east of the Lower Jordan Valley receive appreciable amounts of precipitation and aquifers there contain fresh $(500-700 \mu \mathrm{S} / \mathrm{cm}) \mathrm{me}-$ teoritic groundwater. When the groundwater infiltrate down into the older formations of the Upper Cretaceous rocks, which contain evaporate residues its salinity gradually increases $(1200-1800 \mu \mathrm{S} / \mathrm{cm})$ and it joins the Lower Cretaceous sandstone body. In this area, the groundwater tables of the deep sandstone aquifer series and that of the Upper Cretaceous calcareous rock series start to coincide, so that further north, in Irbed area and north of it, the deep groundwater table becomes higher in elevation than that of the Upper Cretaceous rock series and accordingly, the deep groundwater moves upwards into the Upper Cretaceous aquifers and recharge them in order to discharge as thermal mineralized ground water in Himma and other springs in the downstream reaches of the Yarmouk River (El-Nasser, 1991). Therefore, extraction from any aquifer in this area and from whatever depth is to be considered taken from the whole groundwater stock. And since the salinity of the deep sandstone aquifer is high compared to the Upper Cretaceous aquifers, there will be no advantage of extracting the deep groundwater and desalinate it for use, because such extractions are effectively taken from the whole interconnected groundwater body. In addition, extractions of the deep part of the groundwater body will negatively impact Himma and other springs' discharges in the area which are used for therapeutic purposes.

The same conditions prevail also in the basalt area of Jabal Druz, and hence the same argumentation is valid there concerning any thinking of water extraction from the deep groundwater body.

4) The Pan-Handle area receives very small amounts of rainfall $50-90 \mathrm{~mm} / \mathrm{yr}$. and hence groundwater recharge is very restricted to infiltration along wadis and some desert playas. The area is, in places, covered by recent Quaternary rocks overlying Miocene, Eocene and Paleocene sandstones and chalk marls of a thickness of about $700 \mathrm{~m}$, underlain by $695 \mathrm{~m}$ of Paleocene-Maastrichtian marls forming an aquiclude. The underlying Cenomanian to lower Maastrichtian rocks 
composed of silicified limestone, phosphatic chert, marl, dolomite, and marly limestone measure around $220 \mathrm{~m}$ forming a series of excellent to poor aquifer. In general, with the exception of the local surficial aquifer containing some groundwater, the main groundwater body is found in poorly developed aquifers with some good yield aquifer layers containing low-salinity brackish water (1300 $2500 \mu \mathrm{S} / \mathrm{cm}$ ) (GITEC et al., 1995). The Lower Cretaceous sandstone aquifer has here a thickness of around $150 \mathrm{~m}$ but it contains brackish water with salinities of up to a few thousand $\mu \mathrm{S} / \mathrm{cm}$. The Cretaceous sediments with a thickness of some $1300 \mathrm{~m}$ form one interconnected aquifer having one groundwater table. The deeper groundwater bodies found in the Triassic, Jurassic and older rock formations contain water with high salinity and are hydraulically interconnected with the overlying rock units building together a basal groundwater body, supporting all overlying groundwater bodies. The interconnectedness of the different aquifer/semi-aquifer series is strongly enhanced by the deep-seated faults along and surrounding the Sirhan Depression

Groundwater extractions from any depth or in any place in this area go on the account of the stored, only partly renewable groundwater stocks partly fed by groundwater flows originating in the basalt area covering the western part of the Pan-Handle.

\section{Conclusions}

The series of rocks of Pre-Cambrian clastics to Lower Cretaceous sandstones overlying the granitic Basement Complex build one extended aquifer system underlying the whole territory of Jordan, containing fresh water in southern Jordan. Towards north, in Ras en Naqab area, where Upper Cretaceous calcareous rocks containing some evaporate residues overlie the older sandstone aquifer system the salinity of the groundwater, especially in the upper parts of the sandstone system starts to increase as a result of downward percolation of the groundwater from the Upper Cretaceous into the underlying sandstone aquifer system. Due to some thick marl and claystone beds in the Upper Cretaceous rock package two groundwater tables start to develop; one in the deep sandstone aquifer complex and another within the Upper Cretaceous calcareous aquifer/aquiclude series, but the two groundwater bodies remain hydraulically interconnected, especially in areas affected by faulting and fracturing accompanying the formation of Jafr Depression, Ras en Naqab Escarpment, Jordan Rift Valley and other structures.

The intercalation of the Permian, Triassic and Jurassic, sandstone and siltstone rocks in the area east of the central and northern part of the Dead Sea does not create any change in the interconnectedness of Pre-Cambrian to Lower Cretaceous rock series because the Permian, Triassic and Jurassic rocks form aquifers and the groundwater table remains the same for the entire rock column from Paleozoic into Lower Cretaceous. And therefore, any extraction of groundwater from any part of the sandstone series is considered extraction from the 
same aquifer. The thermal, mineralized springs issuing along the Dead Sea and southern Jordan Valley escarpment originate from this deep groundwater body. Hence, any extractions from this aquifer series, especially in the area east of the Dead Sea and its eastern highlands will negatively affect the springs' water discharges (Zarqa Ma'in, Zara, Ibn Hammad, Weda'a, Suweima) used for therapeutic purposes and might lead to their seizure.

In the highlands lying northeast of the Dead Sea, the groundwater tables of the deep sandstone system; Per-Cambrian to Lower Cretaceous; and that of the Upper Cretaceous formations start to coincide, and in the area north of Ajlun the deep sandstone groundwater table becomes higher than that of the Upper Cretaceous one and the groundwater starts to leak upwards from the deep sandstone groundwater body into the shallow calcareous one.

Here also extractions from the deep sandstone groundwater will affect the shallow groundwater and it will be similar to extracting the water from the shallow calcareous aquifer which is already taking place by extractions from Wadi $\mathrm{Al}$ Arab and Mukheiba wells.

The Pan-Handle area is covered by a shallow surficial aquifer of Eocene to Miocene ages composed of sandstone, chalk limestone, and chert nodules of about $100 \mathrm{~m}$ in thickness containing fresh to brackish water. It is separated by the Bituminous Marl Formation from the underlying Upper Cretaceous calcareous aquifer and the Lower Cretaceous sandstone aquifer containing none renewable brackish to salty water. Here extraction of the deep groundwater will go on the account of the whole groundwater stock and will result in the down percolation of the fresh surficial groundwater body into the saline deep groundwater bodies. Large scale extractions of $10 \mathrm{~s}$ of millions of cubic meters a year will deplete the aquifers in a short time and will lead to increasing groundwater salinity, by mobilizing evaporate residues.

The above summary shows that the plans advanced by some policy-makers and experts in the water sector to extract the deep brackish to salty groundwater do not mean accessing new water resources, but that such extractions will be on the account of groundwater presently used for drinking, irrigation, therapeutic and other uses. In addition, such extractions will deprive the country of its base of groundwater body, which supports all overlying groundwater bodies and therefore, any extraction from the deep aquifers' groundwater will cause downward percolation of fresh shallow aquifers' groundwater into the deep aquifers' sandstone system and that is quasi extractions from the shallow fresh groundwater bodies.

Therefore, any plan to exploit the deep aquifer system in Jordan is a misleading concept and is scientifically considered as a fallacy policy.

\section{Conflicts of Interest}

The authors declare no conflicts of interest regarding the publication of this paper. 


\section{References}

Bajjali, W., Clark, I., \& Fritz, P. (1997). The Artesian Thermal Groundwaters of Northern Jordan: Insights into Their Recharge History and Age. Journal of Hydrology, 192, 355-382.

Bandel, K., \& Salameh, E. (2013). Geologic Development of Jordan: Evolution of Its Rocks and Life (277 p). University of Jordan Press.

https://www.researchgate.net/publication/275946617

Bender, F. (1975). Geology of the Arabian Pennisula, Jordan (136 p). U.S. Geological Survey Professional Paper 560-I, 3 Plates, USGS Publications Warehouse.

BGR: Bundesanstalt fuer Bodenforschung und Rohstoffe (1997). Investigations of the Regional Basalt Aquifer System in Jordan and Syria, E/ESCWA/ENR/1996/1. UN Publications.

BGR: Federal Institute for Geosciences and WAJ: Water Authority of Jordan (1996). Groundwater Resources of Northern Jordan, Volume 3. Structural Features of the Main Hydrogeological Units.

Burdon, D. (1959). Handbook of the Geology of Jordan (p. 82). Benham and Company Ltd.

El-Nasser, H. (1991). Groundwater Resources of the Deep Aquifer System in NW Jordan -Hydrogeological and Hydrochemical Quasi 3-Dimensional Modeling, Hydrogeology and Umwelt, H.3. Wùrzburg.

EXACT (1998). Overview of Middle East Water Resources (44 p). Executive Action Team (EXACT) of the Middle East Water Resources Working Group.

https://www.researchgate.net/publication/317833058_Overview_of_Middle_East_Wate r_Resources

GITEC, HIS, \& GEMT (1995). Groundwater Investigations in the Hammad and Sirhan Basins. Ministry of Water and Irrigation.

Gnaneswar, V. G. (2018). Desalination of Deep Groundwater Aquifers for Freshwater Supplies, Challenges and Strategies. Groundwater for Sustainable Development, 6, 87-92. https://doi.org/10.1016/j.gsd.2017.11.002

Ibrahim, K. M. (1993). The Geologic Framework for Harrat Ash Shaam basaltic Super-Group and Its Volcano-Tectonic Evolution (p. 33). Natural Resources Authority (NRA).

JICA: Japan International Cooperation Agency (1996). The Study on Brackish Groundwater Desalination in Jordan. Yachiyo Engineering Co., Ltd. Mitsui Mineral Development Engineering Co., Ltd.

Margana, A., Borgstedt, A., Subah, A., \& Hajali, Z. (2009). Groundwater Resources Management. Delineation of Surface Water Protection Zones for the Wala Dam. Technical Report No. 12.

MoWI (2016). Anuual Report. Ministry of Water and Irrigation. http://waterjo.mwi.gov.jo/Ar/DocLib/\%D8\%A7\%D9\%84\%D8\%AA\%D9\%82\%D8\%B1 \%D9\%8A\%D8\%B1\%20\%D8\%A7\%D9\%84\%D8\%B3\%D9\%86\%D9\%88\%D9\%8A\%2020 16\%20-\%20english.pdf

NRA: Natural Resources Authority (2008). Geology Directorate, Geological Mapping Division. Ministry of Energy and Mineral, Open Files.

NRA: Natural Resources Authority (2016). Geology Directorate, Geological Mapping Division. Ministry of Energy and Mineral, Open Files.

NWMP: National Water Master Plan (1977). Budesanstalt fuer Geowissenshaften und Rohstoffe BGR, Natural. Authority Jordan NRA, and Ministry of Water and Irrigation MoWI. 
Parker, D. H. (1970). Investigation of the Sandstone Aquifers of East Jordan. UNDP

Salameh, E., \& Rimawi, O. (1997). Curative Water in Jordan. Publication of the Ministry of Tourism and Antiquities.

Salameh, E. (1996). Water Quality Degradation in Jordan (179 p). Friedrich Ebert Stiftung and the Royal Society for the Conservation of Nature.

Salameh, E. (2008). Over-Exploitation of Groundwater Resources and Their Environmental and Socio-Economic Implications: The Case of Jordan. Water International, 33, 55-68. https://doi.org/10.1080/02508060801927663

Salameh, E., Shteiwi, M., \& Al-Raggad, M. (2018). Water Resources of Jordan: Political, Social and Economic Implications of Scarce Water Resources. World Water Resources, 1. https://doi.org/10.1007/978-3-319-77748-1

Salameh, E., \& Shteiwi, M. (2019). Water Security in Jordan (pp. 19-33). Water Security and the Sustainable Development Goals.

Salameh, E., \& Tarawneh, A. (2017). Assessing the Impacts of Uncontrolled Artesian Flows on the Management of Groundwater Resources in the Jordan Valley. Environmental Earth Sciences, 76, Article No. 291. https://doi.org/10.1007/s12665-017-6610-0

Salameh, E., \& Udluft, P. (1985). The Hydrodynamic Pattern of the Central Part of Jordan (pp. 35-53). Geologisches Jahrbuch.

Subah, A. (2019) Jordan to Drill "Fossil Water" Wells Half a Mile Underground. https://www.nbcnews.com/news/world/jordan-drill-fossil-water-wells-half-mile-under ground-n930426

Tarawneh, A. (2015). Effects of the Saline Groundwater Pumping from the Triassic and Jurassic Formations on the Groundwater System in the Area Downstream of King Talal Dam. University of Jordan, Faculty of Science.

Van der Boom, G., \& Suwwan, O. (1966). Report on the Geological and Petrological Studiesof the Plateau Basalts in NE Jordan. Unpublished Report GGM. 